\title{
Fiscal Policy and Economic Cycles in Congo
}

\author{
Antoine Ngakosso \\ Faculté des Sciences Economiques, Université Marien Ngouabi, Brazzaville, Congo \\ Email: ngakosso_antoine@yahoo.fr
}

How to cite this paper: Ngakosso, A. (2018) Fiscal Policy and Economic Cycles in Congo. Modern Economy, 9, 174-189. https://doi.org/10.4236/me.2018.91011

Received: August 19, 2017

Accepted: January 15, 2018

Published: January 18, 2018

Copyright (C) 2018 by author and Scientific Research Publishing Inc. This work is licensed under the Creative Commons Attribution International License (CC BY 4.0).

http://creativecommons.org/licenses/by/4.0/

\begin{abstract}
The purpose of this paper is to respond on discretionary fiscal policy on economic cycles in Congo. A fiscal reaction function developed by Huart [1] was thus estimated over the 1989-2015 period. It comes out from the results that the fiscal policies carried out during this period were both counter-cyclical and pro-cyclical expansionist. This resulted in instability of the public debt and an accumulation of payment arrears.
\end{abstract}

\section{Keywords}

Fiscal Policy, Economy Cycles, Fiscal Rule, Debt Instability, Congo

\section{Introduction}

The world economies are subject to fluctuations that require the reaction of public authorities based ondiscretionary fiscal policies for economic stabilization purposes. In fact, following a period of unrest, instability and crises from the First World War to the aftermath of the Second World War, Keynesian discretionary fiscal policies proved successful until the late 1960s. Yet, the 1970s were marked by the international monetary system crisis $^{1}$ and the two oil shocks ${ }^{2}$ challenged the Keynesian approach about public finances due to the unexpected consequences of the juxtaposition of inflation and structural unemployment ${ }^{3}$. Thus, faced with the failures of Keynesian fiscal stimulus policies, supply-side theorists argued in favor of supply-side policies that lead to the reduction of public spending ${ }^{4}$ and/or taxes.

Based on rational expectations, the authors of the new classical economy [2]

\footnotetext{
${ }^{1}$ It was this crisis that had led to the end of the dollar-gold parity.

${ }^{2}$ Respectively in 1973 and 1979.

${ }^{3}$ In other words, Keynesian policies have been called into question because of the stagflation experienced by the advanced countries.

${ }^{4}$ These are the so-called fiscal consolidation policies that are opposed to the Keynesian stimulus policy.
} 
[3] highlighted the inefficiency and ineffectiveness of discretionary policies and argued for regulation policies. The effectiveness of the rules is assessed in relation to their effects on the cost of borrowing, on the one hand, and budgetary discipline on the other. The question of the effectiveness of the rules in terms of the effects on the cost of borrowing refers to the sustainability of public finances. On the other hand, the one concerning the effects of the rules on budgetary discipline consists of the compatibility of the budgetary rules aiming to the budgetary policy. Based on the objectives of fiscal policy according to the three functions theorized by Musgrave [4], this second concern arises in terms of a priori opposition between the rules whose objective is the sustainability of public finances and the function which assumes that in case of an economic shock, the deficitlevel as well as the debt level may increase. In these circumstances, the position about budgetary rules depends on the role assigned to fiscal policy in the area of cyclical stabilization. There are two types of theoretical orientation for this purpose.

Firstly, the theories lay emphasis on budgetary policy in stabilizing cyclical conditions and advocating flexible rules. Generally speaking, the proponents of these theories considerthe budgetary rules as an obstacle. Nevertheless, they argue for the compatibility of cyclical stabilization and fiscal discipline in such a way that the direction of discretionary fiscal policies is countercyclical regardless of cyclical conditions.

Secondly, the theories consider fiscal policy inefficient regarding economic stabilization. Indeed, fiscal policy must be allocated to the sustainability of public finances and be limited to the automatic stabilizers, with monetary policy stabilizing the economy. However, these theoriesstipulate that cyclical fiscal policy may only be necessary in three cases [5] [6]. The first case is about a situation of deflation risk ${ }^{5}$, i.e., when the economy is in a liquidity trap situation. The second case concerns a situation wherein monetary policy undermines the credibility of the central bank. The third case deals with a fixed parity situation, with capital mobility where monetary policy is mobilized for the objective of the exchange ratestability.

Notwithstanding these theoretical orientations, the financial and economic crisis that occurred at the end of 2007, coupled with the effects of fluctuations in oil prices, has revived the debate on the effectiveness of fiscal stabilization policy. Thus, during the last decade, several studies carried out within the fiscal policy framework have focused on the reaction of discretionary fiscal policy on economic cycles.

Congo, a member of the $\mathrm{CEMAC}^{6}$, is subject to the budgetary rules in force in the countries of this zone, undergoing economic cycles like any other countries, hence it is pertinent to analyze the fiscal policies implemented by its different governments in connection to economic cycles. In other words, it is worth

${ }^{5}$ The situation where nominal interest rates and inflation are close to null.

${ }^{6}$ Economic and Monetary Community of Central African States. 
investigating the nature of fiscal policies in Congo since 1989 (pro-cyclical, counter-cyclical, and acyclic).

The analysis of the discretionary fiscal policy in the specific case of the Congo is legitimate because of the fixed parity between the CFA ${ }^{7}$ currency and the euro, the capital mobility between the euro zone and the FCFA zone. In fact, the determination of budgetary policies in Congo should permit to draw lessons from the past in order to reorient the strategy of conducting discretionary fiscal policy in this country.

This article is organized into three sections: the review of the literature is presented in Section 2; the budgetary rules in force in Congo are described in Section 3; the estimation model and results are dealt with in Section 4; Section 5 concludes this study.

\section{Review of the Literature}

There is an abundant literature on both theoretical and empirical literature regarding the analysis of the reaction of discretionary fiscal policy on economic cycles.

From a theoretical standpoint, the literature distinguishes four currents globally. First, the Keynesian theory claims that the reaction of fiscal policy to changes in the economic cycle must be contra-cyclical. Indeed, when the economy is in anunderemployment situation, i.e. an economic downturn, governments must pursue a discretionary fiscal stimulus policy to stabilize economic activity in the short term. Keynes believes that such a fiscal stimulus policy is more effective than a monetary policy. A fiscal policy is viewed as counter-cyclical ${ }^{8}$, if public authorities resort to the decline (increase) in public spending and the increase (decrease) in taxes in the economic (economic recession) phase. Countercyclical policy helps to stabilize the economic cycle since it reinforces the effects of automatic stabilizers by supporting demand during a downturn in economic activity and by reducing it during overheatingperiods.

In a country within a monetary union, a cyclical fiscal policy at the national level is necessary to stabilize the specific cyclical economic fluctuations, where there are nominal or real rigidities in economy or where adjustment mechanisms are lacking alternatives (price and wage flexibility, labor and capital mobility, financial integration, fiscal integration). In adverse times, a countercyclical expansive fiscal stance aims to support aggregate demand. In favorable periods, a countercyclical restrictive fiscal stance stems from the need to reduce public deficits (possibly accumulated during unfavorable periods) and to reduce public surpluses in order to secure room for maneuver for the future. The budgetary balance should be improved during favorable periods (by affecting the surplus of revenues for deleveraging, for example) in order to allow its deterioration during adverse periods (the automatic stabilizers involving less tax revenues and more ${ }^{7}$ Franc of Financial Cooperation in Africa

${ }^{8}$ A counter cyclical fiscal policy may be countercyclical or restrictive countercyclical expansionary. 
social spending). Otherwise, the risk is that a government, which pursues procyclical expansionary fiscal policy during favorable periods (deterioration of the fiscal balance), is doomed to conduct a pro-cyclical restrictive fiscal policy during unfavorable periods (improvement of the budgetary balance), because its indebtedness becomes excessive and will have difficulties to borrow from financial markets. However, in a monetary union, the fiscal policies of each country must reconcile economic stabilization with the rules of fiscal discipline.

Then, based on David Ricardo's idea that a loan is a deferred tax, and on the other hand, on rational expectations, Barro [3] theory of Ricardian equivalence argues for the fiscal policyneutrality. Barrocriticizes the fiscal stimulus policy and stresses that the agents foresee an increase in tax rates to repay the loan; in advance of this tax increase in the future, they increase their savings. In this effect, the rational expectations of agents will therefore counteract the effectiveness of the fiscal stimulus. For Barro, the State must maintain the fiscal pressure and stable public spending in the economic cycle so that during recession periods the income falls and the deficits increase in order to allow public spending to remain fairly constant during the cycle. Such a fiscal policy is acyclical $^{9}$. In other words, fiscal policy is acyclical if budgetary authorities keep public spending and fiscal pressure constant throughout the cycle to only allow automatic stabilizers to act.

In addition to counter cyclical and acyclic fiscal policies, the theoretical literature also identifies procyclical fiscal policy. Indeed, a fiscal policy is procyclical, if the public authorities increase (decrease) public expenditure and decrease (increase) the taxes in theexpansion phase (recession). Such a fiscal policy strengthens the amplitude of the economic cycle which is detrimental in terms of inflation and employment.

Finally, proponents of the threshold effects of fiscal policy suggest the coexistence of different fiscal regimes contingent on public debt. In this respect, three schemes can be distinguished. Firstly, when economic slowdown with debt is below the sustainability threshold (or the level of public spending is below the optimal size of the state), expansionary fiscal counter-cyclical policies must be applied in order to reinforce the effects of automatic stabilizers. Secondly, beyond the optimal size of the State, in the event of economic recovery, countercyclical restrictive fiscal policies must be pursued to reduce the level of public expenditure to the optimal level [7] to which acyclic budgetary policies will apply. It is in this context that unconventional fiscal policy tenants suggest that during a crisis, discretionary stimulus measures should be targeted, timely and temporary [8] to the extent that when the crisis is over, the opposite steps must be taken. Thirdly, with a debt ratio above the threshold of sustainability followed by an economic slowdown, a budgetary contraction would have nonKeynesian or anti-Keynesian effects. In other words, a fiscal contraction (i.e.

\footnotetext{
${ }^{9}$ For Barro, the acyclical fiscal policy, which is an optimal fiscal policy.
} 
restrictive pro-cyclical fiscal policies) would be neutral or even favorable to economic activity. Several mutually exclusive explanations, based on both demand and supply mechanisms, are advanced. First, the explanation for demand effects is based on the existence of a signal effect [9]. Indeed, in case of anunsustainable debt, agents expect to be charged the repayments themselves and increase their savings as a result of an increase in the deficit. Secondly, the explanation on the supply side lies in the adjustment of public expenditure (especially by the wage bill, despite the resulting short-term political cost), which does not lead to distortions generating an increase in taxes [10].

As things stand, even if all economists disagree about fiscal policies in the management of cycles, they nevertheless recommend avoiding procyclical fiscal policies.

On the empirical level, several studies have been carried out on both developed and developing countries. In general, these studiesshowed that fiscal policies in developing countries have beenprocyclical [11]-[19]. The pro-cyclical nature of fiscal policies in these countries can be explained by the sharp fluctuations in the tax base. Indeed, in these countries it is difficult for the public authorities to allow a large budgetary surplus to be realized in a period of expansion in front of pressure from different social groups and lobbies for an increase in public expenditure. In order to mitigate the risk of inefficient use of additional resources and to benefit the private sector, policy makers are led to increase spending and reduce tax rates simultaneously. In a recession, because they have not saved resources, they are obliged to cut spending and raise tax rates. The pro-cyclical bias in the fiscal policy stance in these countries can also be accounted of by the government inability to borrow during bad times due to absence or imperfections in capital markets [20] and, on the other hand, to save during good times because of a "voracity effect" [21] [22], i.e. an irrationality. This pro cyclical bias is rather strong thanks to factors such as corruption[15], the poor quality of institutions [23], the debt unsustainability [24], heterogeneous preferences for income redistribution [25], political incentives far from the general interest [12], high production volatility [26] [27] [28] [29] [30] ${ }^{10}$ and the effects of price cycles of financial assets $[31]^{11}$.

On the other hand, by decomposing expenditures and revenues, studies on developing countries ${ }^{12}$ demonstrated that during expansion periods, public spending has been pro-cyclical, countercyclical and acyclical.

In developed countries, fiscal policies have been mainly countercyclical but acyclic in some countries. However, Lane [27] [28] showed that the cyclical

${ }^{10}$ Greater economic volatility increases the likelihood that government revenue and expenditure forecasts will be erroneous.

${ }^{11}$ In times of rising asset prices, tax revenues are higher, due to capital gains and wealth effects on consumption, which can lead to tax cuts or increases in government spending. Conversely, in periods of declining asset prices, governments face a fall in tax revenues and may be encouraged to increase taxes or even cut government spending.

${ }^{12}$ These are studies whose results showed the procyclical nature of fiscal policies in the developing countries cited at the beginning of the empirical review. 
nature of fiscal policy differs from one country to another in OECD countries. Indeed, it is countercyclical in advanced countries, whereas it is likely to be procyclical in countries whose production is more volatile and where political power is more dispersed. However, at the disaggregated level of public spending, the behavior of transfers and interest on debt is countercyclical, while that of current expenditure and public investment is procyclical.

\section{The Budgetary Policy Rules in Force in the Congo}

The fiscal policy rules in force in Congo are those of the CEMAC. Fiscal policy in the CEMAC countries is guided by the four nominal convergence criteria which were revised in 2001 and came into force in January $2002^{13}$. The first criterion is the non-grant base ${ }^{14}$ budget balance expressed in terms of a GDP percentage which must be positive or null. In each State, this criterion has several objectives: to achieve a budgetary surplus to clear the full interest on the debt, to finance part of the public investment and to play a decisive role in managing the specific shocks that may affect the economic sector. However, this criterion has the disadvantage of not taking considering the risk of decreasing oil resources, investments financed by external borrowing and does not encourage governments to practice counter-cyclical fiscal policies [32] but rather leads to a procyclical bias in public spending [19]. In general, Congo met this criterion during the period covered by this study. The second criterion is the debt ratio which should not exceed 70\% of GDP to avoid crossing debt sustainability thresholds and possible crowding-out effects. Until 2008, this criterion was not respected since Congo reached the completion point of the Heavily Indebted Poor Countries (HIPC) initiative in January 2010. Further to the debt relief from the HIPC initiative, this threshold of $70 \%$ of GDP being very high can lead to excessive re-indebtedness ${ }^{15}$. However, this second criterion failed to provide a rapid framework for action by the budgetary authorities. Indeed, action on the public debtlevel involves action on the budgetary balance whose effects on the debt level are felt with a time lag. This defect can be corrected by fixing alert thresholds in order to bring about a corrective action on the balance before the ceiling is reached ${ }^{16}$. The third criterion is the non-accumulation of internal and external arrears on the management of the current period. This is a liquidity indicator that assesses the financing difficulties that a country may face in its economic development. Indeed, internal arrears are likely to increase inflationary pressures due to the anticipatory effects of economic agents [33]. The infla-

\footnotetext{
${ }^{13}$ These are the first criteria to which must be added the second-tier criteria: Wage/tax revenue $<$ $35 \%$; Investments financed from own resources $>20 \%$; Current account balance/GDP $>5 \%$; Tax rate $>17 \%$; Foreign exchange rate of foreign exchange assets $>20 \%$.

${ }^{14}$ This balance, again called the basic primary balance, excludes interest on debt and investment expenditure financed by own resources

${ }^{15}$ According to the IMF's June 2017 mission, Congo's public debt would be just over 90\% of GDP, while the HIPC debt relief had reduced the debt ratio to 15\% of GDP. Since more than 2013, the aggregate of arrears in domestic wage payments amounts to more than 15 billion FCFA.

${ }^{16}$ Such a mechanism has been put in place in Poland. The debt ceiling is set at $60 \%$ of GDP, with two alert thresholds set at $50 \%$ to $55 \%$ of GDP, respectively.
} 
tionary pressures affect the business climate. On the other hand, external arrears may affect the investment and credibility of debtor States vis-à-vis the international financial community. Cumulative arrears look like a variable for adjusting the budget balance because Congo has hardly met this criterion during the period of our analysis ${ }^{17}$. Fiscal policies in Congo have failed to reconcile economic stabilization with the rules of budgetary discipline because of the failure to meet the debt level criteria and the absence of overdue payments. This has certainly led to the pro-cyclical nature of fiscal policies during times of economic overheating. Finally, the last criterion is the average annual inflation rate which should not exceed $3 \%$. This criterion enables to minimize the inflation differentials between the CEMAC member countries and prevents the risk of real exchange rate misalignment according to the purchasing power parity theory but also the deterioration of competitiveness. This is a monetary policycriterion which also imposes constraints on the conduct of fiscal policy because the regime in the CEMAC countries is monetary dominated, that is, the Ricardian regime. As has been described, these budgetary rules do not prevent member countries from pursuing discretionary fiscal policies. Nevertheless, for the compatibility of economic stabilization and fiscal discipline, the direction of discretionary fiscal policies should be counter-cyclical both in adverse periods (deterioration of the fiscal balance when economic growth slows) and in favorable periods (improvement of budgetary balance when economic growth accelerates).

Overall, these rules have the disadvantage of not fixing a structural deficit rule as a percentage of GDP in order to restore the medium-term budget balance which should be able to face unexpected fluctuations or economic shocks. But since Congo is a country whose public finances solely depend on oil exports and its price evolution on the international market, the conventional methods used ${ }^{18}$ to anchor fiscal policy seem inadequate to its economy. Taking this particular situation into consideration, the anchoring of fiscal policy in Congo must combine the objective of fiscal sustainability with greater flexibility in public spending to respond to shocks and to maintain the cyclical role of public finance of the State. By so doing, the rules currently in force should at least be complemented by three rules: a fiscal rule based on the oil price, i.e., a structural primary balance rule with smoothing of oil prices; a structural income rule for non-oil revenues, i.e. a primary balance rule excluding natural resources, and a rule for a public spending growth ${ }^{19}$.

First of all, the rule based on the oil price ${ }^{20}$ can be used to smooth the oil revenues and the planned public spending. When real prices are above (lower) the budgeted, revenues are higher (lower) than revenue forecasts, resulting in a surplus (a deficit) that gives rise to accumulation of the stabilization fund. It then

\footnotetext{
${ }^{17}$ Since more than 2013, the aggregate of arrears in domestic wage payments amounts to more than 15 billion FCFA.

${ }^{18}$ This is a combination of flow-related rules (in the form of a budgetary target, often adjusted to the cycle) and stocks (the ratio of public debt to GDP).

${ }^{19}$ These are the IMF's recommendations to countries rich in natural resources.

${ }^{20} \mathrm{This}$ is a rule of the structural primary balance with price smoothing.
} 
follows that the higher the desired smoothing rate, the less the budgetary receipts are sensitive to price shocks, the more stable the stabilization fund needed to effectively prevent shocks.

With respect to the non-oil structural revenue rule, excluding the cyclical component of output ${ }^{21}$, it aims to reduce revenue volatility and the pro-cyclical nature of the budget. Indeed, non-oil structural revenues can be calculated by adjusting non-oil revenues to the ratio of potential output to real output.

Finally, the rule of public expenditure growth permits to limit the procyclicality of fiscal policy. It can also be used when there is insufficient absorption capacity ${ }^{22}$. This last rule is generally combined with a price-based rule. All these two rules can be elaborated only in countries rich in natural resources whose exhaustion of reserves is within a very long-term horizon. These IMF-recommended rules, however, require the establishment of a stabilization fund to help maintain or smooth State spending in exceptional periods in order to strengthen the credibility of budgetary rules. Since budgetary rules based on approaches from the budgetary framework of the resource-rich countries proposed by the International Monetary Fund (IMF) are not yet applied in Congo, our assessment of fiscal policy will focus on the primary structural balance which includes both primary non-oil and non-oil production, as well as total production (oil and non-oil).

\section{Model for Determining the Cyclicality of Fiscal Policy}

To deal with the problem raised, we are going to test the relationship between the change in the primary structural budget balance and the change in the output gap.

\subsection{Variables of the Model}

Three variables are used to determine the cyclicality of fiscal policy in Congo: the change in the primary structural budget balance (SBSP), the change in the output gap (PF) and the public debt-to-GDP ratio due to its effects on the primary structural budget balance.

The primary structural balance $(S S P)$ is equal to the budgetary balance $\left(S S^{23}\right)$, subtracting the interest payments (i.D). Thus, $S S P=S S-i x D$.

With: $i=$ interest on debt; $D=$ amount of debt for the previous year; structural budgetary balance $(S S)^{24}=S B-\varepsilon(Y-\bar{Y})$; primary structural fiscal balance $=S B-\varepsilon(Y-\bar{Y})-i D$; budget balance $(S B)=$ revenue-expenditure; $\varepsilon=\frac{d S b}{d(y-\bar{z})}>0$, with $y=\log Y$ and $\bar{y}=\log \bar{Y} . Y$ : produced production;

\footnotetext{
${ }^{21}$ This is the rule for the structural primary balance excluding natural resources. This is a rule that applies to countries where the depletion of natural resources takes place within a relatively short time horizon.

${ }^{22}$ It can be used for overheating or high current deficits.

${ }^{23}$ The structural budget balance is deduced from Taylor's [5] fiscal policy rule that $S B=S S+\varepsilon(Y-\bar{Y})$

${ }^{24}$ There is underemployment and therefore unused production capacity.
} 
$\bar{Y}$ : potential output; $\varepsilon$. elasticity of the budgetary balance at the output gap: it is a measure of the sensitivity of the budget to the economic cycle, that is to say, the size of automatic stabilizers.

The analysis of the change in the primary structural budgetary balance leads to trace the action of the discretionary fiscal policy. When this change is stable from one year to the next, the action of fiscal policy is neutral; if this variation increases, there is a discretionary tightening of fiscal policy; if it decreases, there is a discretionary relaxation of fiscal policy. On the other hand, the direction of fiscal policy is determined by cyclical conditions, which are defined by the sign of the variation in the output gap. Thus, fiscal policy is countercyclical (procyclical) if the correlation between the two variables is positive (negative): the fiscal balance deteriorates (improves) when the change in the output gap is negative or improves (deteriorates) when the change in the output gap is positive. Fiscal policy is acyclical when the output gap is null. In other words, the cyclical balance is positive when $(y-\bar{y})>0$; the cyclical balance is negative when $(y-\bar{y})<0$, the cyclical balance is neutral when $y=\bar{y}$. It follows, finally, that a discretionary easing in a cyclical downturnperiod is a countercyclical policy, and in a cyclical expansionperiod is a procyclical policy. On the other hand, a discretionary tightening in a period of cyclical downturn is a pro-cyclical policy, and in a period of cyclical expansion, it is a countercyclical policy.

\subsection{Specification of the Model}

An examination of the empirical literature reveals that there are at least two approaches to study the cyclical nature of fiscal policy. The first focuses on the correlation between the fiscal deficit or the cyclically adjusted balance and the output gap, while the second analyzes the relationship between fiscal policy instruments and the business cycle. Thus, in order to analyze the cyclical nature of fiscal policy in Congo from 1989 to 2015, we have chosen the model developed by Huart [1] which follows the models of the first approach. The interest of this model concerns the estimation of a budgetary reaction function which takes into account the problem of endogeneity ignored by other models. Moreover, this model has the peculiarity of discarding the possible effect of fiscal policy on the economic cycle. Thus, like Huart [1], we will test the relationship between the change in the primary structural budget balance and the change in the output gap. For this purpose, we assume that the dependent budgetary variable (primary structural budget balance, or SBSP in abbreviation) can be explained by the primary structural budget balance of the previous period (SBSP at time $t-1$ ), the change in the production gap (EP) and the public debt-to-GDP ratio at the end of the previous period (DP at time $t-1$ ).

$$
\operatorname{SBSP}_{t}=\beta_{0}+\beta_{1} \mathrm{SBSP}_{t-1}+\beta_{2} \mathrm{DEP}_{t}+\beta_{3} \mathrm{DP}_{t-1}
$$

where the index $t$ represents a given year, the symbol $\Delta$ the first difference operator (expressing a variable in variation between two consecutive periods).

The presence of the primary structural budget balance of the previous period 
$\left(\mathrm{SBSP}_{\mathrm{t}-1}\right)$ among the explanatory variables of the current structural primary budget balance $\left(\mathrm{SBSP}_{\mathrm{t}}\right)$ reflects the influence of the initial budgetary conditions on the budgetary decisions of a given time in particular the inertia observed in the evolution of fiscal policy variables due to implementation delays or measures that are difficult to reverse. The sign of the coefficient $\beta_{1}$ is expected to be positive.For the parameter $\beta_{2}$ attached to the output variance (EP) variable, it denotes a contra-cyclical (pro-cyclical) discretionary fiscal policy if it is positive (negative). As for the public debt-to-GDP ratio, it represents a "discipline" effect: a positive $\beta_{3}$ parameter indicates a motive for stabilizing the debt under fiscal policy (a higher debt-to-GDP ratio entails budgetary efforts to improve the primary structural budget balance).

\subsection{Results of the Estimate and Their Implications}

Thefirst step is to present the results of the estimation, and then to analyze their implications (Table 1).

\subsubsection{The Results of the Estimation}

The data cover the period from 1989 to 2015 and their sources are presented in Table A1 in the Appendix. Since the period is short (less than 30 observations), the technique used is quarterly to increase the sample size and have more consistent estimators. This technique is recommended by some international institutions like the $\mathrm{IMF}^{25}$.

We first evaluated the value of the coefficient $\varepsilon$ (see Table A2 in the Appendix) to calculate the structural budget balance. The value of $\varepsilon$ is 0.098 . A decrease of one point in the output gap leads to a decrease in the cyclical surplus (in-

Table 1. Results of the estimate.

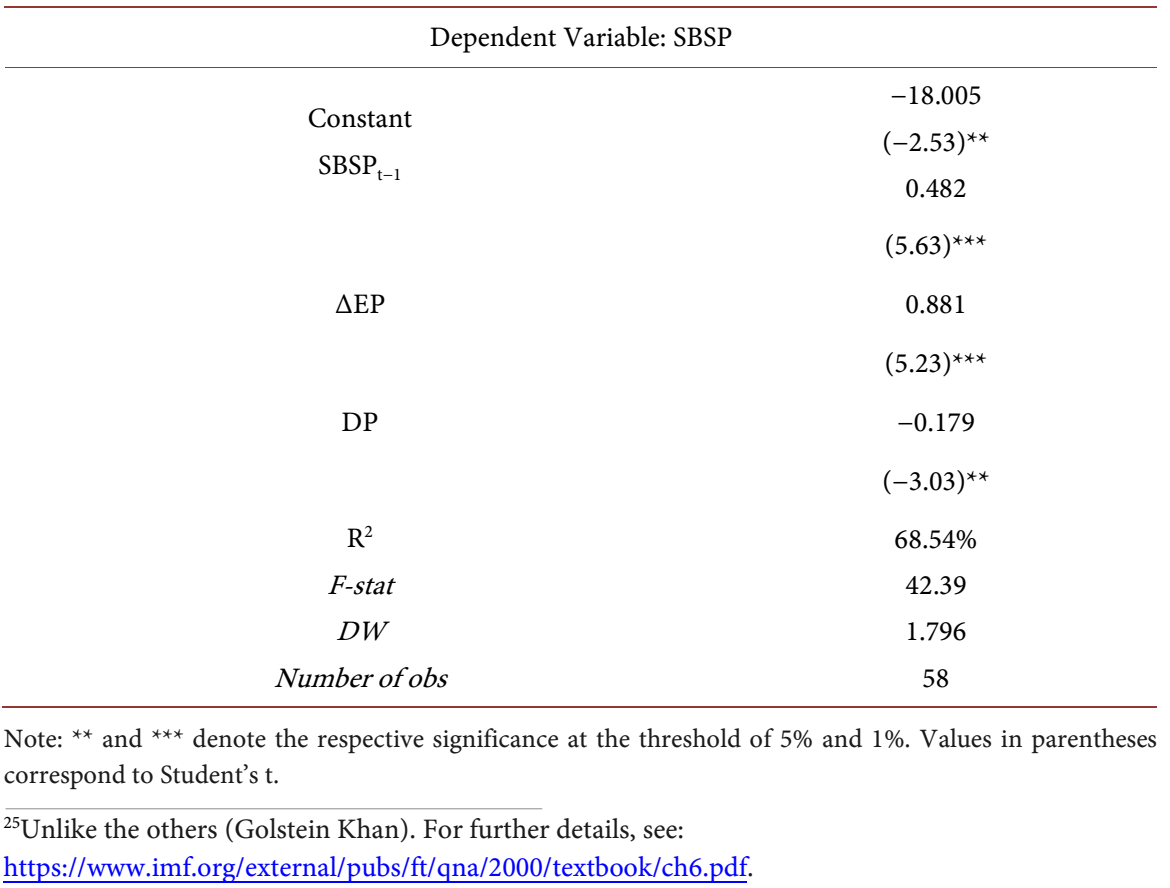


creases the cyclical deficit) by $0.098 \%$. This means low efficiency of automatic stabilizers in reducing fluctuations. This low efficiency can be explained by the absence of the policy of taking care of the unemployed thus rendering inoperative the mechanism of the automatic stabilizers that pass through this type of public expenditure.

Since the estimate is based on an autoregressive model, the most relevant test is the autocorrelation of errors (Durbin's h-test). Here the value of the Durbin Watson (DW) statistic shows an error independence. The other tests are appended, including the nullity of the average residual test, we accept null (the expectation of the error is null). The stationarity test was not carried out because it is not relevant to stationary the variables that would not be stationary (the data have already undergone a quarterly transformation and differentiating them necessarily entails a loss of information additional). Moreover, the notion of fallacious regression is rejected here because the DW statistic is much greater than the coefficient of determination $\mathrm{R}^{2}$. All these elements corroborate the robustness of the results. The model is globally significant (Fisher test, probinf 0.05), the adjusted $\mathrm{R}^{2}$ is equal to $68 \% ; \beta_{1}=0.482$ and $\beta_{2}=0.881$ are significant and gave the expected sign (positive); $\beta_{3}=-0.179$ is significant but has a negative sign (contrary to what was expected).

\subsubsection{Interpretation of Results}

The results of the estimation show that the coefficient $\beta \_2$ attached to the output gap (EP) is positive. So, if we consider only the coefficient $\beta_{2}$, the Congolese fiscal policy from 1989 to 2015 would have been countercyclical. Such a policy would therefore have aimed to reinforce the effects of automatic stabilizers which would comply with the recommendations of the currently dominant paradigm in economic policy. The Congolese budgetary authorities would therefore have avoided pro-cyclical restrictive fiscal policies (lower public spending and higher taxes during economic downturns). However, the coefficient $\beta_{3}$ attached to the public debt-to-GDP ratio is negative and therefore contrary to the expected sign, indicating the instability of the public debt, characteristic of a pro-cyclical expansionary fiscal policy. Thus, taking into account both $\beta_{2}$ and $\beta_{3}$, the fiscal policy pursued by the Congolese authorities during this research period concerned was therefore both a counter-cyclical expansionary and a procyclical expansionist (increase in public expenditure and a fall in revenues taxes during the recovery period). Finally, Congolese public authorities use fiscal policy to support the economy during periods of economic downturn, but they have not implemented restrictive fiscal policies in good times to avoid the overheating of the economy. Such a fiscal policy has led to instability of the public debt or even to its unsustainability leading to the accumulation of payment arrears and the risk of payment shortage. Indeed, budgetary policy has not enabled the authorities in charge of its implementation to reconcile economic stabilization with the rules of budgetary discipline. This resulted in higher public spending during the recovery periods. This fact has aggravated the budget deficits financed, on 
the one hand, by the loan become practically unsustainable ${ }^{26}$, and on the other hand, by the practice of cumulative payment arrears. This is a typical fiscal policy for heavily indebted countries dependent on natural resources. In these resource-rich countries where income from these resources tends to dominate the cyclical cycle, governments resort to increased spending in times of rising prices (Medas and Zakharova, 2009). Indeed, such countries tend to pursue countercyclical fiscal policies during a downturn, and pro-cyclical fiscal policies in a recovery phase.

Thus, the Congolese State would benefit from a counter-cyclical expansionary fiscal policy (increase in public spending and fall in public revenues during a downturn) and a counter-cyclical restrictive fiscal policy (falling public spending and rising government revenues during a recovery period) in order to avoid the risk of an increase in public debt that could lead to the unsustainability of public finances. Indeed, a countercyclical restrictive fiscal policy would enable to identify the budgetary surpluses needed to reduce public debt. The fiscal ad-justment in Congo during the recovery period should be based mainly on the public expenditure component as compared to revenue.

Moreover, since the effectiveness of automatic stabilizers is low, it is recommended to implement active public policies. In other words, the Congolese government should make greater use of the structural component of fiscal policy as an instrument of economic policy.

Finally, Congo's economy depends heavily on a natural resource, oil, the countercyclical nature of fiscal policy should be strengthened by the implementation of three budgetary rules: a structural primary balance rule with smoothing of oil prices; a structural income rule for non-oil revenues, anda public expenditure growth rule. However, the credibility and effectiveness of these rules should require the combination of the establishment of a sovereign stabilization fund to limit spending and smooth public revenues which should allow an active counter-cyclical policy. Moreover, since the output gap is negative, Congo is experiencing involuntary unemployment in the sense of Keynes. As a matter of fact, the State should intervene to improve the functioning of markets and the efficiency of public investment so that private production is more important and national production reaches its potential level. In other words, the State should also consider the influence of structural policies that can play an important role in the evolution and capacity of the economy to withstand shocks. The Congolese State should intervene within the framework of the functions of resource allocation and income redistribution in order to promote the development of the additional production capacity needed to diversify the economy. Indeed, a diversified economy is more resilient to shocks.

\section{Conclusion}

The objective of this research was to determine the cyclicality of Congo's fiscal policy from 1989 to 2015. The results of the estimation of a fiscal reaction

${ }^{26}$ According to the IMF mission in June 2017, Congo's public debt is just over 90\% of GDP. 
function showed that the fiscal policy implemented by different successive governments in Congo have been both counter-cyclical expansionist and procyclical expansionist leading to the instability of the public debt that could lead to the unsustainability of public finances. The hypothesis of the pro-cyclical restrictive fiscal policy was rejected in favor of the counter-cyclical restrictive fiscal policy. On the other hand, the countercyclical expansionist fiscal policy has been confirmed. The non-cumulative arrears and debt thresholds were not met due to pro-cyclical expansionary fiscal policies. The Congolese authorities would therefore benefit from counter-cyclical fiscal policies both during periods of economic downturn and resumption so that the current budgetary rules can be respected.

\section{References}

[1] Huart, F. (2011) Les politiques budgétaires sont-elles contra-cycliques dans la zone euro? Revue de I'OFCE, 116, 149-172.

[2] Kydland Finn, E. and Prescott, E.C. (1997) Rules Rather than Discretion: The Inconsistency of Optimal Plans. The Journal of Political Economy, 85, 473-492.

[3] Barro, R. (1974) Are Government Bonds Net Wealth? Journal of Political Economy, 82, 1095-1118.

[4] Musgrave, R.A. (1959) The Theory of Public Finance: A Study in Public Economy. McGraw-Hill, New York.

[5] Taylor, J.B. (2000) Reassessing Discretionary Fiscal Policy. Journal of Economic Perspectives, 14.

[6] Taylor, J.B. (2009) The Lack of an Empirical Rationale for a Revival of Discretionary Fiscal Policy. American Economic Review, 99.

[7] Alesina, A., Michalopoulos, S. and Papaioannou, E. (2012) Ethnic Inequality. NBER Working Papers 18512, National Bureau of Economic Research, Inc.

[8] Spilimbergo, A., Symansky, S. and Schindler, M. (2009) Fiscal Multipliers. IMF Staff Position Note.

[9] Sutherland, A. (1997) Fiscal Crises and Aggregate Demand: Can High Public Debt Reverse the Effects of Fiscal policy? Journal of Public Economics, 65, 147-162.

[10] Alesina, A. and Ardagna, S. (1998) Tales of Fiscal Adjustments. Economic Policy, 27, 489-545.

[11] Gavin, M. and Perotti, R. (1997) Fiscal Policy in Latin America. NBER Macroeconomics Annual, 12, 11-71. https://doi.org/10.1086/654320

[12] Talvi, E. and Végh, C. (2005) Tax Base Variability and Procyclical Fiscal Policy in Developing Countries. Journal of Development Economics, 78, 156-190. https://doi.org/10.1016/j.jdeveco.2004.07.002

[13] Braun, M. (2001) Why Is Fiscal Policy Procyclical in Developing Countries? CIPPEC, ms, May.

[14] Kaminsky, G.I., Reinhart, C.M. and Vegh, C.A. (2004) When It Rains, It Pours: Procyclical Capital Flows and Macroeconomic Policies. NBER Working Paper No. 1080.

[15] Alesina, A. and Tabellini, G. (2008) Why Is Fiscal Policy Often Procyclical? Journal of the European Economic Association, 6, 1006-1036.

https://doi.org/10.1162/JEEA.2008.6.5.1006 
[16] Du Plessis, S.A.B. and Sturzenegger, F. (2007) Identifying Aggregate Supply and Demand Shocks in South Africa. A Working Paper of the Department of Economics and the Bureau for Economic Research at the University of Stellenbosch.

[17] Du Plessis, S. and Boshoff, W. (2007) A Fiscal Rule to Produce Counter-Cyclical Fiscal Policy in South Africa. Stellenbosch University Working Paper 13/2007, Stellenbosch.

[18] Lledo, V., Yackovlev, I. and Gadenne, L. (2009) Cyclical Patterns of Government Expenditures in Sub-Saharan Africa: Facts and Factors. IMF Working Paper 09/274, Washington DC.

[19] Guillaumont, J. and Tapsoba, S.J.-A. (2011) Pro cyclicité de la politique budgétaire et surveillance multilatérale dans l'Union Economique et Monétaire Ouest Africaine. Revue africaine de développement, 23, 172-189.

[20] Adler, G. (2008) Original Sin and Procyclical Fiscal Policy: Two Sides of Same Coin? IMF Working Paper, No. 08/209.

[21] Tornell, A. and Lane, P. (1999) The Voracity Effect. American Economic Review, 89, 22-46. https://doi.org/10.1257/aer.89.1.22

[22] Akitoby, B., Clements, B., Gupta, S. and Inchauste, G. (2006) Public Spending, Voracity, and Wagner's Law in Developing Countries. European Journal of Political Economy, 22, 908-924. https://doi.org/10.1016/j.ejpoleco.2005.12.001

[23] Calderon, C., Duncan, R. and Schmidr-Hebbel, K. (2004) Institutions and Cyclical Properties of Macroeconomic Policies. Central Bank of Chile Working Papers, No. 285.

[24] Alberola, E. and Montero, J.M. (2006) Debt Sustainability and Procyclical Fiscal Policies in Latin America. Banco de Espana Work Paper No. 0611.

[25] Woo, J. (2006) Why Do More Polarized Countries Run more Pro-Cyclical Fiscal Policy? Mimeo, DePaul University, Chicago.

[26] Coricelli, F. and Ercolani, V. (2002) Cyclical and Structural Deficits on the Road to Accession: Fiscal Rules for an Enlarged European Union. CEPR Discussion Paper No. 3672. http://www.cepr.org/pubs/dps/DP3672.asp

[27] Lane, P.R. (2003a) Business Cycles and Macroeconomic Policy in Emerging Market Economies. International Finance, 6, 89-108. https://doi.org/10.1111/1468-2362.00109

[28] Lane, P.R. (2003b) The Cyclical Behaviour of Fiscal Policy: Evidence from the OECD. Journal of Public Economics, 87, 2661-2675. https://doi.org/10.1016/S0047-2727(02)00075-0

[29] Debrun, X., Faruqee, H. and Beetsma, R. (2004) Has Fiscal Behavior Changed under the European Economic and Monetary Union? IMF World Economic Outlook, Chap 2.

[30] Manasse, P. (2006) Procyclical Fiscal Policy: Shocks, Rules, and Institutions-A View from Mars. IMF Working Paper, No. 06/27. https://doi.org/10.5089/9781451862874.001

[31] Jaeger, A. and Schuknecht, L. (2004) Boom-Bust Phases in Asset Prices and Fiscal Policy. IMF Working Paper, No. 04/54.

[32] Guérineau, S., Guillaumont Jeanneney et Florian Léon (2015) Viabilité budgétaire et renforcement du dispositif de surveillance multilatérale au sein de la CEMAC. Fondation pour les Etudes et la Recherche sur le Développement International (Ferdi) et Université d'Auvergne.

[33] De Boissieu, C. (1985) Elément d'une analyse de la rigidité à la baisse du taux d'intérêt. EconomieAppliquée, No. 1. 


\section{Appendix}

Table A1. Data presentation.

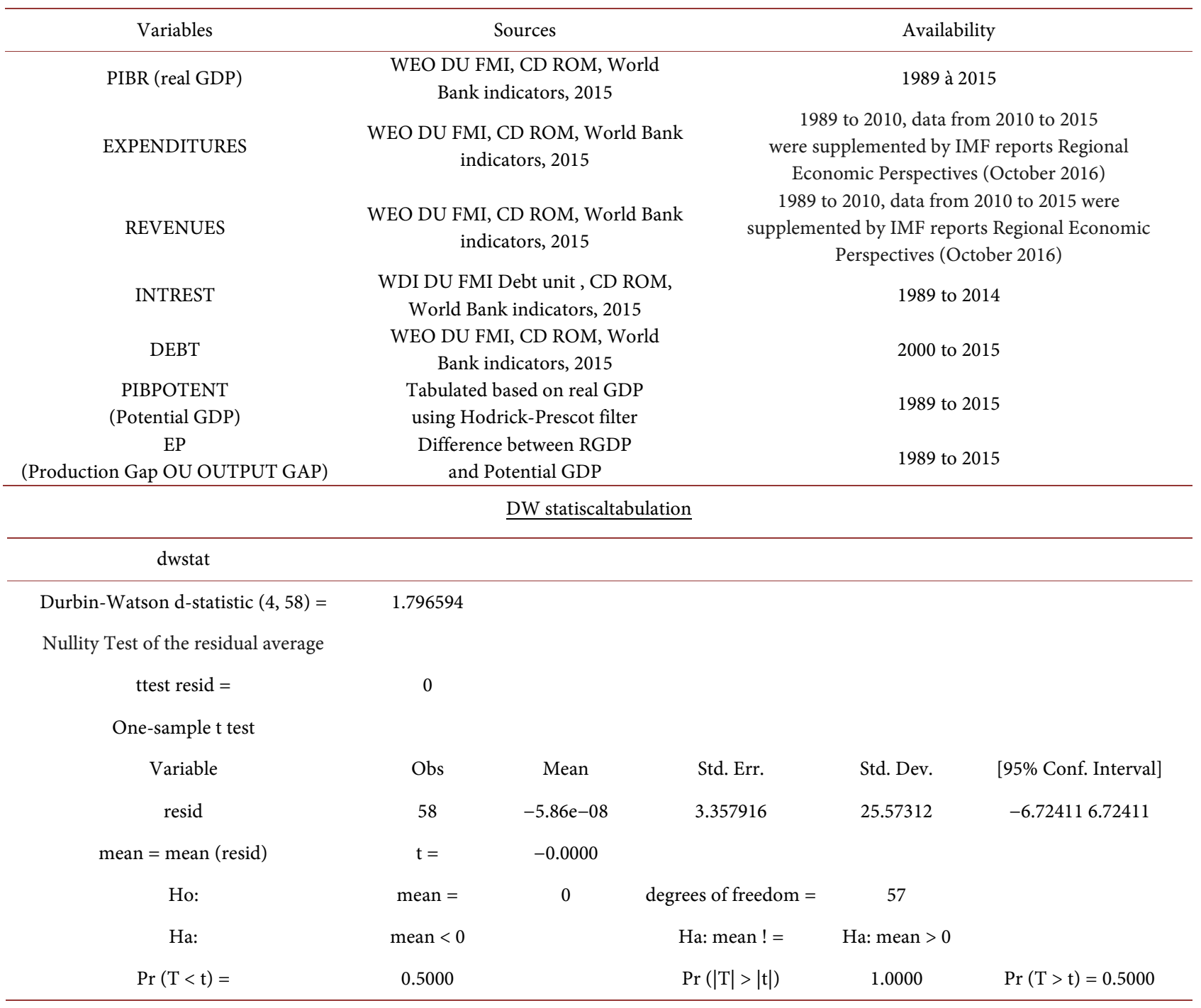

Table A2. Balance sensitivity.

\begin{tabular}{ccccc}
\hline Source & SS & df & MS & Number of obs $=108$ \\
\hline Model & 360.25221 & 1 & 360.25221 & $\mathrm{~F}(1,106)=2.84$ \\
Residual & 13463.3273 & 106 & 127.012522 & Prob $>\mathrm{F}=0.0951$ \\
& & & $\mathrm{R}$-squared $=0.0261$ \\
Total & 13823.5795 & 107 & 129.192332 & Adj R-squared $=0.0169$ \\
sbpib & Coef & Std. Err & $\mathrm{t}$ & Root MSE $=11.27$ \\
ep & 0.0983215 & 0.0583806 & 1.68 & P > |t| [95\% Conf. Interval] \\
_cons & 1.383364 & 1.084455 & 1.28 & -0.01742370 .2140667 \\
\end{tabular}

$\mathrm{e}=0.098$, it is positive and significant at $10 \%$ threshold. 
Table A3. Estimation results.

\begin{tabular}{|c|c|c|c|c|c|}
\hline Source & SS & df & MS & \multicolumn{2}{|c|}{ Number of obs $=58$} \\
\hline & & & & \multicolumn{2}{|c|}{$\mathrm{F}(3,54)=42.39$} \\
\hline Model & 87794.893 & 3 & 29264.9643 & \multicolumn{2}{|c|}{ Prob $>F=0.0000$} \\
\hline Residual & 37277.125 & 54 & 690.317129 & \multicolumn{2}{|c|}{$\mathrm{R}$-squared $=0.7020$} \\
\hline & & & & \multicolumn{2}{|c|}{ Adj R-squared $=0.6854$} \\
\hline Total & 125072.018 & 57 & 2194.24593 & \multicolumn{2}{|c|}{ Root MSE $=26.274$} \\
\hline sbsppib & Coef & Std. Err & $\mathrm{t}$ & \multicolumn{2}{|c|}{$\mathrm{P}>|\mathrm{t}|$ [95\% Conf. Interval] } \\
\hline \multicolumn{6}{|l|}{ sbsppib } \\
\hline L1 & 0.4823017 & 0.0856293 & 5.63 & 0.000 & 0.31062530 .6539781 \\
\hline ep & 0.881842 & 0.1686129 & 5.23 & 0.000 & 0.54379361 .219891 \\
\hline \multicolumn{6}{|l|}{$\mathrm{dp}$} \\
\hline L1 & -0.1791998 & 0.0590646 & -3.03 & 0.004 & $-0.2976172-0.0607825$ \\
\hline _cons & -18.00547 & 7.124904 & -2.53 & 0.014 & $-32.29004-3.720898$ \\
\hline
\end{tabular}

